\title{
Effects of 3,4-dimethylpyrazole phosphate (DMPP) on nitrification and the abundance and community composition of soil ammonia oxidizers in three land uses
}

\author{
Xiuzhen Shi ${ }^{1} \mathbb{D} \cdot$ Hangwei $\mathrm{Hu}^{1} \cdot$ Jizheng $\mathrm{He}^{1,2} \cdot$ Deli Chen $^{1} \cdot$ Helen Charlotte Suter ${ }^{1}$
}

Received: 17 May 2016/Revised: 21 June 2016 / Accepted: 2 July 2016 / Published online: 15 July 2016

(C) Springer-Verlag Berlin Heidelberg 2016

\begin{abstract}
The application of the nitrification inhibitor, 3,4dimethylpyrazole-phosphate (DMPP), is considered as an effective strategy to mitigate agricultural nitrogen loss. However, the inhibitory effect of DMPP on nitrification is variable and the importance of the soil microbial community composition to the variability is poorly understood. In this study, nine soils were collected across three land uses to investigate the impact of DMPP on nitrification and associated dynamics of ammonia oxidizers in a 28-day microcosm incubation. The results showed that the efficacy of DMPP at inhibiting net nitrification rates varied highly from no effect to $63.6 \%$ during the first week of incubation. The abundance of ammonia-oxidizing bacteria (AOB), rather than ammoniaoxidizing archaea (AOA), was significantly correlated with nitrate concentrations across three land uses and significantly inhibited by DMPP addition. DMPP had higher efficacy in neutral and alkaline wheat and vegetable soils, compared with pasture soils. Canonical correspondence analysis suggested that soil $\mathrm{pH}$ was the most influential factor explaining the community composition of AOB and AOA in the collected soils. However, neither ammonium nitrate nor DMPP addition had a significant effect on the community composition of $\mathrm{AOB}$ or $\mathrm{AOA}$ during the incubation indicated by non-metric multidimensional scaling ordination. Taken together, our findings indicated that DMPP slowed nitrification by inhibiting the growth of $\mathrm{AOB}$, and
\end{abstract}

Xiuzhen Shi

shxzh87@hotmail.com

1 Faculty of Veterinary and Agricultural Sciences, The University of Melbourne, Parkville, Victoria 3010, Australia

2 State Key Laboratory of Urban and Regional Ecology, Research Center for Eco-Environmental Sciences, Chinese Academy of Sciences, Beijing 100085, China
DMPP application affected the abundance of AOB more than the ammonia oxidizer community composition.

Keywords 3,4-Dimethylpyrazole-phosphate · Ammonia-oxidizing archaea $\cdot$ Ammonia-oxidizing bacteria . Abundance $\cdot$ Community composition

\section{Introduction}

Nitrogen (N)-based fertilizer is applied extensively in agriculture as an essential element for plant growth (Gilsanz et al. 2016). According to the prediction of the International Fertilizer Industry Association (IFA), the global demand for $\mathrm{N}$ fertilizers will continuously increase and reach approximately 161 million metric tonnes in 2018 (IFA 2014). However, a major concern associated with the use of synthetic $\mathrm{N}$ fertilizers is the substantial $\mathrm{N}$ losses into the environment and the low nitrogen use efficiency (NUE) (Chen et al. 2008). Furthermore, the rising costs of synthetic $\mathrm{N}$ fertilizers have strengthened farmers' commercial incentive to reduce $\mathrm{N}$ fertilization and as a consequence $\mathrm{N}$ losses (Ernfors et al. 2014). Nitrification is a critical component in the $\mathrm{N}$ cycle, which causes $\mathrm{N}$ losses in the form of nitrate $\left(\mathrm{NO}_{3}{ }^{-}\right)$ leaching and nitrous oxide $\left(\mathrm{N}_{2} \mathrm{O}\right)$ emissions from agricultural systems (Wakelin et al. 2014; Chen et al. 2015). Nitrate leaching could trigger waterway eutrophication and drinking water contamination (Philippot et al. 2007). $\mathrm{N}_{2} \mathrm{O}$ is a potent greenhouse gas, with about 300 -fold greater warming potential than $\mathrm{CO}_{2}$ on a per molecule basis, and is also involved in destruction of the stratospheric ozone layer (Hu et al. 2015a). Therefore, major efforts have been devoted to decreasing nitrification rates to retain $\mathrm{N}$ in the soil for plant uptake (Ernfors et al. 2014; Wakelin et al. 2014).

The incorporation of nitrification inhibitors (NIs) into $\mathrm{N}$ fertilizers is widely adopted as an efficiency-enhanced strategy 
to mitigate $\mathrm{N}$ losses through reducing nitrification rates (Akiyama et al. 2009). NIs are chemical compounds capable of modifying the active site of ammonia monooxygenase (AMO) and causing the formation of polypeptides, thus resulting in the inactivation of AMO activity and delay in nitrification (McCarty and Bremner 1989). Ammonia oxidation, as the rate-limiting step of nitrification, is catalyzed by AMO encoded by the amoA gene within the following two distinct groups of nitrifying microbes: ammonia-oxidizing bacteria (AOB) and ammonia-oxidizing archaea (AOA) (BrochierArmanet et al. 2008; Purkhold et al. 2000). Of the available NIs, 3,4-dimethylpyrazole phosphate (DMPP) has been widely used together with synthetic $\mathrm{N}$ fertilizers (Weiske et al. 2001; Di and Cameron 2011; Liu et al. 2015) and animal manure (Hatch et al. 2005; Fangueiro et al. 2009; Maienza et al. 2014). To achieve comparable effects, DMPP requires much lower application rates than other NIs such as dicyandiamide (DCD) (Chaves et al. 2005; Chen et al. 2008). More importantly, no negative effect of DMPP on non-target microorganisms in soils has been reported (Tindaon et al. 2012; Kong et al. 2016). The inhibition of nitrification by DMPP was previously thought to be through indiscriminately binding to the complex of membrane-bound proteins and inactivating the AMOcontaining AOB (Kleineidam et al. 2011; Benckiser et al. 2013). This perception, however, was challenged by the recent studies of Dong et al. (2013) and Florio et al. (2014), which provided evidence that DMPP inhibited AOA as well. Therefore, the underlying contribution of $\mathrm{AOA}$ and $\mathrm{AOB}$ to the DMPP-induced inhibition of nitrification is still in debate.

DMPP has been frequently applied in pasture and farming systems, but the inhibitory efficacy was reported to differ largely within and across agricultural systems. For example, studies found that the effect of DMPP on nitrification varied from no effect to $28.2 \%$ in grasslands (Fangueiro et al. 2009; Di and Cameron 2012), from 8.6 to $56.6 \%$ in cropping systems (Weiske et al. 2001; Liu et al. 2013; Migliorati et al. 2014), and from 13.8 to $19.1 \%$ in vegetable production systems (Xu et al. 2005). Environmental variables such as temperature and moisture have been widely studied and considered as key factors controlling the efficacy of DMPP at inhibiting nitrification (Azam et al. 2001; Menéndez et al. 2009, 2012). Recently, Shi et al. (2016) suggested that the efficacy of NIs at reducing the nitrification rates was highly correlated with the abundance and activity of AOB. In contrast, McGeough et al. (2016) found that the efficacy of NIs was largely affected by soil properties such as soil clay and organic matter content. To date, there is limited knowledge regarding the importance of soil microbial community composition to the variable efficacy of DMPP at inhibiting nitrification, which has greatly hindered our ability to assess the efficacy of DMPP in different scenarios.

The main objective of this study was to explore the influence of ammonia oxidizers and land uses on DMPP efficacy. Nine soils across three land uses (pasture, wheat, and vegetable) were incubated following fertilizer application in presence and absence of DMPP in a 28-day microcosm incubation at $25{ }^{\circ} \mathrm{C}$. The following hypotheses were tested: (1) the abundance and/ or community composition of $\mathrm{AOA}$ and $\mathrm{AOB}$ would respond differently to DMPP application, owing to their different physiological characteristics and enzyme systems for ammonia oxidation, and (2) the efficacy of DMPP at inhibiting nitrification would be higher in the wheat and vegetable soils compared to the pasture soils, due to their lower organic matter content.

\section{Materials and methods}

\section{Site descriptions}

Soil samples were collected in October 2015 from nine sites across three land uses (pasture, wheat, and vegetable) in Victoria and New South Wales, Australia. Pasture soils were collected from Dookie (P-DK; $36^{\circ} 25^{\prime} \mathrm{S}, 145^{\circ} 42^{\prime} \mathrm{E}$ ), Glenormiston (P-GN; $38^{\circ} 15^{\prime} \mathrm{S}, 142^{\circ} 52^{\prime} \mathrm{E}$ ), and Finley (P-FL; $35^{\circ} 38^{\prime} \mathrm{S}, 145^{\circ}$ $40^{\prime} \mathrm{E}$ ). Two wheat growing soils were collected from Finley (W$\mathrm{FL}_{1}, 35^{\circ} 33^{\prime} \mathrm{S}, 145^{\circ} 32^{\prime} \mathrm{E} ; \mathrm{W}-\mathrm{FL}_{2}, 35^{\circ} 39^{\prime} \mathrm{S}, 145^{\circ} 37^{\prime} \mathrm{E}$ ) and one from Horsham (W-HS; $36^{\circ} 45^{\prime} \mathrm{S}, 142^{\circ} 07^{\prime} \mathrm{E}$ ). Vegetable growing soils were collected at Clyde (V-CD; $38^{\circ} 08^{\prime} \mathrm{S}, 145^{\circ} 20^{\prime} \mathrm{E}$ ), Werribee (V-WB; $37^{\circ} 56^{\prime} \mathrm{S}, 144^{\circ} 40^{\prime} \mathrm{E}$ ), and Perry Bridge (V$\mathrm{PB} ; 37^{\circ} 59^{\prime} \mathrm{S}, 147^{\circ} 16^{\prime} \mathrm{E}$ ). The soils were classified using the Australian Soil Classification (Isbell 2002).

\section{Soil sampling and physicochemical characterization}

At each site, four surface soil samples $(0-10 \mathrm{~cm})$ were mixed together as a composite sample and passed through a 2-mm sieve. Gravimetric water content was determined by ovendrying sub-samples at $105{ }^{\circ} \mathrm{C}$ for $24 \mathrm{~h}$. Soil $\mathrm{pH}$ was determined using a ratio of 1:5 (fresh soil:water) with an Orion Star A211 pH meter (Thermo Scientific Inc., Melbourne, Australia). Soil organic matter was determined using the $\mathrm{K}_{2} \mathrm{Cr}_{2} \mathrm{O}_{7}$ wet oxidation and colorimetric method as previously described by Walkley and Black (1934). Soil exchangeable $\mathrm{NH}_{4}{ }^{+}-\mathrm{N}$ and $\mathrm{NO}_{3}{ }^{-}-\mathrm{N}$ were extracted using a ratio of 1:5 (fresh soil: $1 \mathrm{M} \mathrm{KCl}, w / v)$ by shaking at $180 \mathrm{rpm}$ for $1 \mathrm{~h}$, and the solution, filtered through a Whatman 42 filter paper, was measured by a Segmented Flow Analyzer $\left(\mathrm{SAN}^{++}\right.$, Skalar, Breda, Holland). Total $\mathrm{N}$ was determined using the classic Dumas method of combustion on an isotope ratio mass spectrometer (Sercon Hydra, Crewe, UK). Particle size analysis was measured using the sieve and hydrometer procedures. Details of the soil physical and chemical properties are shown in Table 1.

\section{Soil microcosm incubation}

The microcosm incubation was established to assess the effects of DMPP addition on nitrification and nitrifiers in 
Table 1 The physical and chemical properties for the soil samples collected from nine sites in three land uses in Australia

\begin{tabular}{|c|c|c|c|c|c|c|c|c|c|}
\hline Soil properties & P-DK & P-GN & P-FL & W-FL 1 & $\mathrm{~W}-\mathrm{FL}_{2}$ & W-HS & $\mathrm{V}-\mathrm{CD}$ & V-WB & V-PB \\
\hline Land use & Pasture & Pasture & Pasture & Wheat & Wheat & Wheat & Vegetable & Vegetable & Vegetable \\
\hline Location & Dookie & Glenormiston & Finley & Finley & Finley & Horsham & Clyde & Werribee & Perry Bridge \\
\hline Mean annual temperature $\left({ }^{\circ} \mathrm{C}\right)$ & 20.9 & 19.1 & 22.9 & 22.9 & 22.9 & 22.7 & 19.9 & 20.5 & 20.3 \\
\hline Mean annual rainfall (mm) & 550 & 779 & 430 & 430 & 430 & 414 & 812 & 538 & 628 \\
\hline Soil order & Chromosol & Dermosol & Sodosol & Sodosol & Sodosol & Vertosol & Podosol & Chromosol & Podosol \\
\hline $\mathrm{pH}$ & 5.65 & 5.55 & 6.28 & 6.37 & 5.49 & 6.37 & 7.02 & 7.96 & 5.44 \\
\hline Soil organic matter $(\%)$ & 5.96 & 5.27 & 7.30 & 5.33 & 2.61 & 3.67 & 3.11 & 1.73 & 1.35 \\
\hline Exchangeable $\mathrm{NH}_{4}{ }^{+}-\mathrm{N}\left(\mu \mathrm{g} \mathrm{g}^{-1}\right.$ soil $)$ & 17.7 & 12.1 & 21.0 & 31.8 & 15.8 & 12.0 & 12.4 & 14.0 & 10.6 \\
\hline $\mathrm{NO}_{3}{ }^{-}-\mathrm{N}\left(\mu \mathrm{g} \mathrm{g}^{-1}\right.$ soil $)$ & 37.8 & 9.3 & 36.9 & 78.5 & 16.7 & 8.3 & 32.3 & 27.9 & 9.0 \\
\hline Total N (\%) & 0.40 & 0.21 & 0.49 & 0.31 & 0.19 & 0.20 & 0.30 & 0.17 & 0.05 \\
\hline \multicolumn{10}{|l|}{ Particle size (\%) } \\
\hline Clay $(<0.002 \mathrm{~mm})$ & 11 & 19 & 8 & 11 & 40 & 3 & 4 & 36 & 5 \\
\hline Silt $(0.002-0.02 \mathrm{~mm})$ & 30 & 14 & 15 & 44 & 11 & 37 & 11 & 23 & 5 \\
\hline Sand $(0.02-2 \mathrm{~mm})$ & 59 & 67 & 77 & 45 & 49 & 60 & 85 & 41 & 90 \\
\hline
\end{tabular}

the nine collected soils. Three treatments involving (1) control, (2) $\mathrm{NH}_{4} \mathrm{NO}_{3}$, and (3) $\mathrm{NH}_{4} \mathrm{NO}_{3}$ plus DMPP were set up in 250-ml plastic vials containing $20 \mathrm{~g}$ of soils (oven dry-weight equivalent) with three replicates. Nitrogen was added at a rate of $75 \mathrm{mg} \mathrm{NH}_{4}{ }^{+}-\mathrm{N} \mathrm{kg}^{-1}$ soil and $75 \mathrm{mg} \mathrm{NO}_{3}{ }^{-}-\mathrm{N} \mathrm{kg}^{-1}$ soil. DMPP was applied in the form of solution at $1 \%$ of the applied $\mathrm{NH}_{4}{ }^{+}-\mathrm{N}$ according to the typical recommended rate (Serna et al. 2000; Pasda et al. 2001). All microcosms were pre-incubated for a week at $25{ }^{\circ} \mathrm{C}$ and then adjusted to $60 \%$ waterfilled pore space (WFPS) after adding treatment solutions (or deionized water for the control treatment). The final bulk density varied between 1.07 and $1.28 \mathrm{~g} \mathrm{~cm}^{-3}$. The vials were closed immediately after treatment solutions were applied and incubated at $25^{\circ} \mathrm{C}$ in the dark for 28 days. During the incubation, the microcosms were aerated through opening the vials every 3 days for $3 \mathrm{~min}$ and moisture loss was replenished every week. Soil samples $(10 \mathrm{~g})$ were collected from three vials on days $0,1,4,7,14$, and 28 for the determination of exchangeable $\mathrm{NH}_{4}{ }^{+}-\mathrm{N}$ and $\mathrm{NO}_{3}{ }^{-}-\mathrm{N}$. Soils $(0.5 \mathrm{~g})$ were collected from the same vials on days 0,7 , and 28 for DNA extraction and molecular analysis.

The equation developed by Persson and Wirén (1995) was used to calculate the net nitrification rates in the first week and over the incubation time (28 days).

$$
\begin{aligned}
& n\left(d_{0}-d_{7}\right)=\left[\left(\mathrm{NO}_{3}{ }^{-}-\mathrm{N}\right)_{d 7}-\left(\mathrm{NO}_{3}{ }^{-}-\mathrm{N}\right)_{d 0}\right] / 7, \\
& n_{(d 0-d 28)}=\left[\left(\mathrm{NO}_{3}{ }^{-}-\mathrm{N}\right)_{d 28}-\left(\mathrm{NO}_{3}{ }^{-}-\mathrm{N}\right)_{d 0}\right] / 28,
\end{aligned}
$$

where $\left(\mathrm{NO}_{3}{ }^{-}-\mathrm{N}\right)_{d 0},\left(\mathrm{NO}_{3}{ }^{-}-\mathrm{N}\right)_{d 7}$, and $\left(\mathrm{NO}_{3}{ }^{-}-\mathrm{N}\right)_{\mathrm{d} 28}$ are the $\mathrm{NO}_{3}{ }^{-}-\mathrm{N}$ concentrations in the soil on days 0,7 , and 28 , respectively.

\section{DNA extraction and quantitative PCR analysis}

Total genomic DNA was isolated from $0.25 \mathrm{~g}$ of soil using MoBio PowerSoil ${ }^{\mathrm{TM}}$ DNA Isolation Kits (MoBio Laboratories, Carlsbad, CA, USA) according to the manufacturer's instructions. The concentration and quality of the extracted DNA were assessed using the NanoDrop ND2000c Spectrophotometer (NanoDrop Technologies, Wilmington, DE, USA).

The abundance of AOB and AOA amoA genes were quantified on a Bio-Rad CFX96 Optical Real-Time PCR Detection System (Bio-Rad, Laboratories Inc, Herculers, CA, USA) using the primer sets amoA1F/amoA2R (Rotthauwe et al. 1997) and CrenamoA23f/CrenamoA616r (Tourna et al. 2008), respectively. The $10 \mu$ reaction mixture contained $5 \mu$ of SYBR Premix Ex $\mathrm{Taq}^{\text {TM }}$ (TaKaRa Biotechnology, Otsu, Shiga, Japan), $0.2 \mu \mathrm{l}$ of each primer $(20 \mu \mathrm{M})$, and $1-10 \mathrm{ng}$ of template DNA. Thermal cycling conditions for the AOB amoA gene were as follows: $30 \mathrm{~s}$ at $95{ }^{\circ} \mathrm{C}, 40$ cycles of $30 \mathrm{~s}$ at $95^{\circ} \mathrm{C}, 30 \mathrm{~s}$ at $56^{\circ} \mathrm{C}$, and $30 \mathrm{~s}$ at $72^{\circ} \mathrm{C}$. As for the AOA amoA gene, thermal cycling conditions were $30 \mathrm{~s}$ at $95^{\circ} \mathrm{C}, 40$ cycles of $30 \mathrm{~s}$ at $95^{\circ} \mathrm{C}, 45 \mathrm{~s}$ at $55^{\circ} \mathrm{C}$, and $45 \mathrm{~s}$ at $72^{\circ} \mathrm{C}$. Standard curves were generated using tenfold serial dilutions of plasmids containing correct inserts of the targeted genes. Melting curve analysis was performed between 75 and $94.5{ }^{\circ} \mathrm{C}$ at the end of each amplification assay to evaluate the specificity of quantitative PCR (qPCR) products. The amplification efficiency for all qPCR runs ranged between 95 and $105 \%$.

\section{Community profiling of the $a m o A$ gene by terminal restriction fragment length polymorphism analysis}

The community composition of $\mathrm{AOA}$ and $\mathrm{AOB}$ in soils on days 0 and 7 of the incubation were determined by terminal restriction fragment length polymorphism (T-RFLP) analysis 

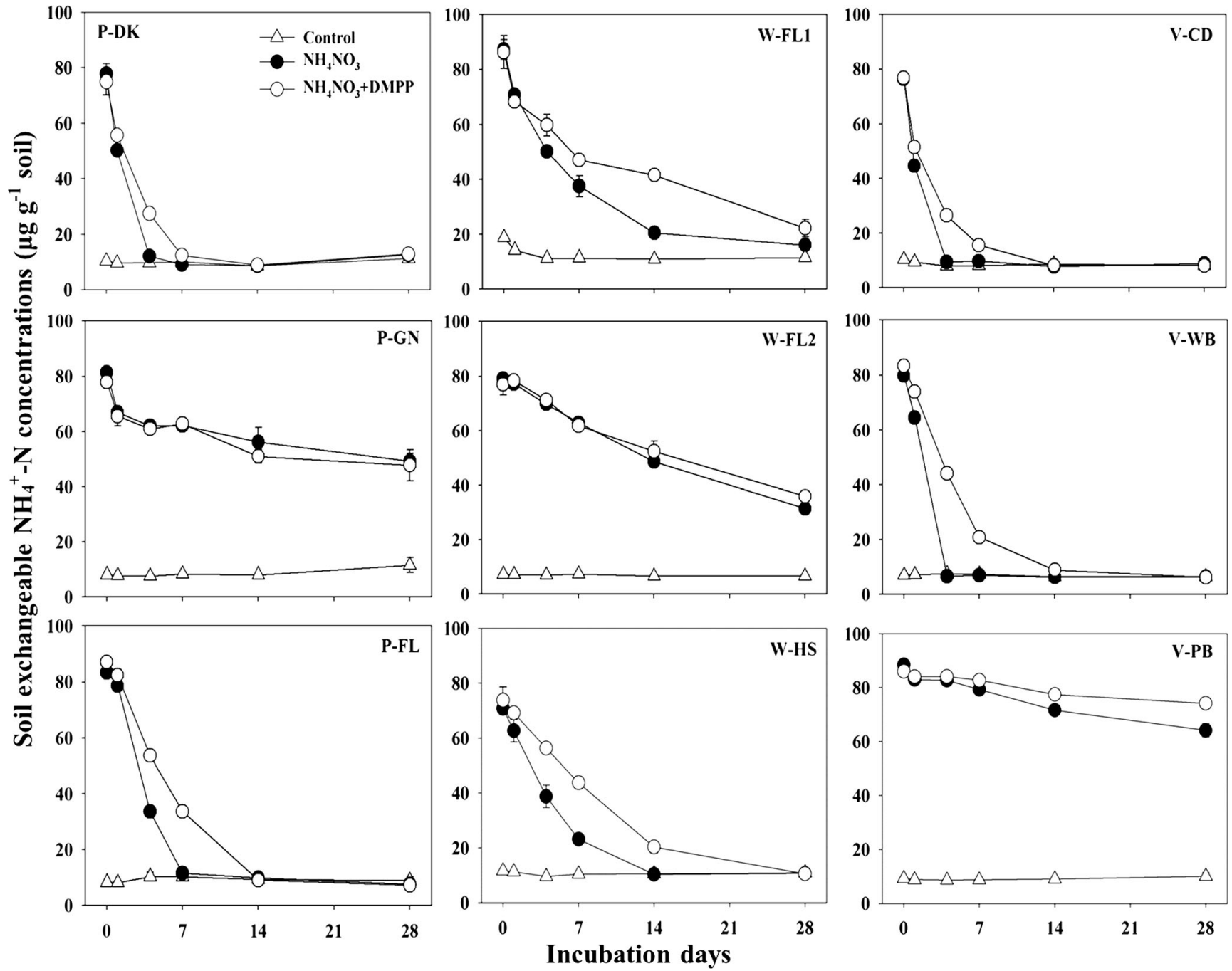

Fig. 1 Changes in the exchangeable $\mathrm{NH}_{4}{ }^{+}-\mathrm{N}$ concentrations of the nine soils in the three land uses (pasture, wheat, and vegetable) during the 28-day microcosm incubation. Error bars represent the standard errors of three replicates

of the amoA genes, using the fluorescently labeled primers FAM-CrenamoA23f/CrenamoA616r and FAM-amoA1F/ amoA2R, respectively (Hu et al. 2015b). The $25 \mu$ PCR reaction mixture contained $2 \mu \mathrm{l}$ of diluted template DNA (1$10 \mathrm{ng}), 0.3 \mu \mathrm{l}$ of each primer $(20 \mu \mathrm{M}), 2.5 \mu \mathrm{l}$ of $\times 10 \mathrm{NH}_{4}$ reaction buffer, $1 \mu \mathrm{l}$ of $\mathrm{MgCl}_{2}$ solution $(50 \mathrm{mM}), 1 \mu \mathrm{l}$ of BSA $(20 \mathrm{mM}), 0.5 \mu \mathrm{l}$ of dNTP mix $(20 \mathrm{mM})$, and $1.5 \mathrm{u}$ of BioTaq DNA polymerase (Bioline, Sydney, Australia). The thermal cycling conditions were as follows: $95^{\circ} \mathrm{C}$ for $5 \mathrm{~min}, 35$ cycles of $30 \mathrm{~s}$ at $95{ }^{\circ} \mathrm{C}, 45 \mathrm{~s}$ at $55^{\circ} \mathrm{C}, 45 \mathrm{~s}$ at $72{ }^{\circ} \mathrm{C}$, followed by $10 \mathrm{~min}$ at $72^{\circ} \mathrm{C}$. The PCR products were purified using the Wizard SV Gel and PCR Clean-Up System (Promega, San Luis Obispo, CA, USA) and quantified using the NanoDrop ND2000c Spectrophotometer.

The restriction digestion was carried out in a $10 \mu \mathrm{l}$ mixture containing $300 \mathrm{ng}$ of purified PCR products, $0.1 \mu \mathrm{l}$ of BSA, $1 \mu \mathrm{l}$ of $\times 10 \mathrm{NE}$ buffer, and $5 \mathrm{u}$ of the restriction enzymes MspI for AOB or RsaI (BioLabs, Sydney, Australia) for AOA. Digests were incubated at $37{ }^{\circ} \mathrm{C}$ for $3 \mathrm{~h}$ and then denatured for $10 \mathrm{~min}$ at $95{ }^{\circ} \mathrm{C}$. Terminal restriction fragments (TRFs) were size separated with an ABI PRISM 3500 Genetic Analyzer (Applied Biosystems, CA, USA) and analyzed using a local southern size-calling method (peaks $>50 \mathrm{bp}$ ) and a peak amplitude threshold setting of 50, using GeneMapper version 4.0 (Applied Biosystems). TRFs with peak height comprising less than $1 \%$ of the total peak height were removed from the downstream analysis, and peaks that differed by less than $1 \mathrm{bp}$ were combined into the same TRF (Singh and Thomas 2006; Hu et al. 2015b). The relative fluorescence abundances of all TRFs were exported for the analysis of community composition.

\section{Statistical analysis}

The amoA gene copy numbers were log transformed prior to statistical analysis to meet normality assumptions. 

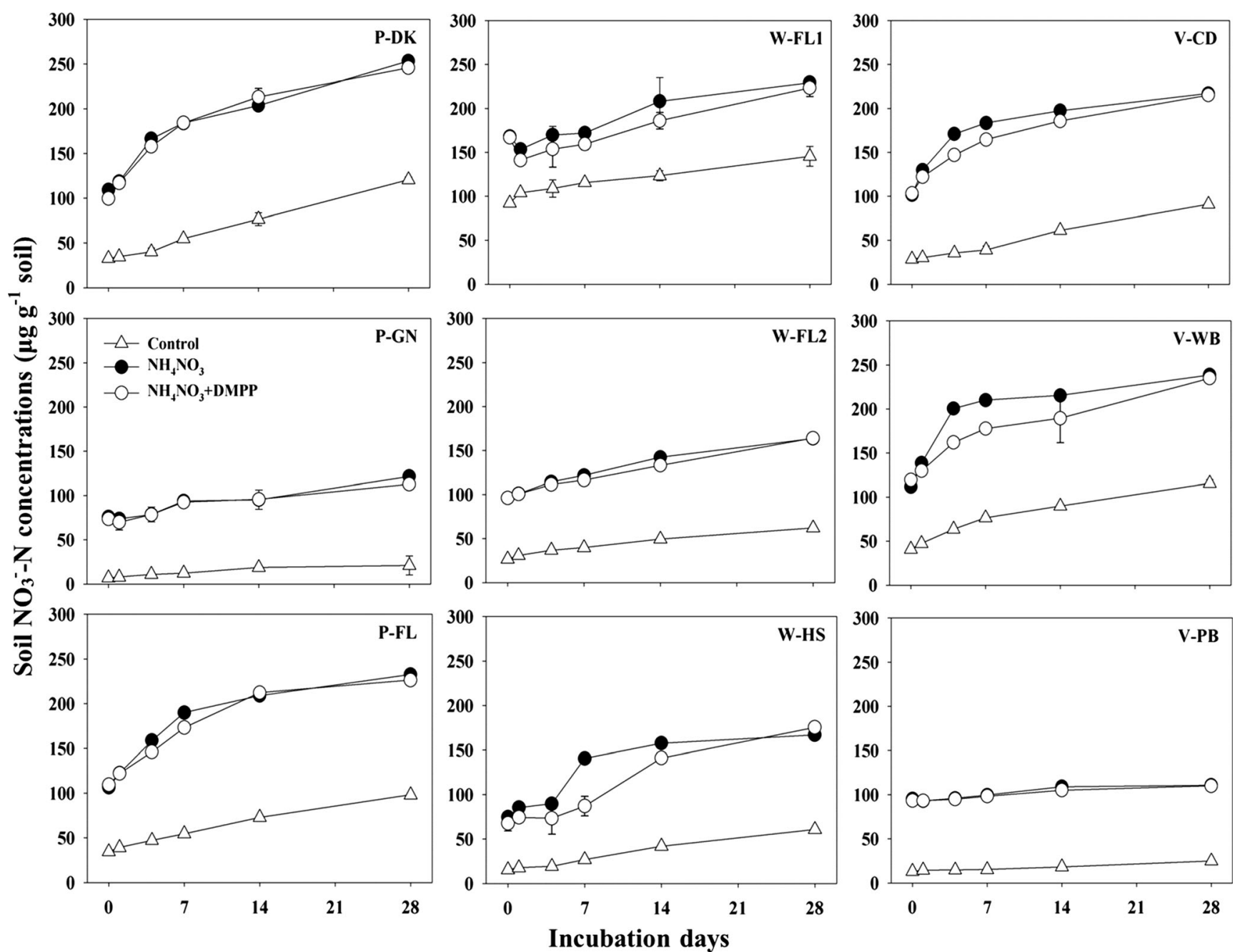

Fig. 2 Changes in the $\mathrm{NO}_{3}{ }^{-}-\mathrm{N}$ concentrations of the nine soils in the three land uses (pasture, wheat, and vegetable) during the soil microcosm incubation. Error bars represent the standard errors of three replicates

One-way analysis of variance (ANOVA) was used to compare net nitrification rates and the amoA gene abundance across treatments in SPSS 19.0 (IBM, USA). Spearman's correlation was performed to assess the correlations between the amoA gene copy numbers and $\mathrm{NO}_{3}{ }^{-}-\mathrm{N}$ concentrations. Difference at $P<0.05$ was considered to be statistically significant. Canonical correspondence analysis was performed with the Monte Carlo permutation test (the number of permutations is 499) to investigate the significant environmental factors influencing the community composition of $\mathrm{AOB}$ and AOA based on the T-RFLP data from soils collected on day 0 using CANOCO 4.5 (Microcomputer Power, Ithaca, NY, USA). Non-metric multidimensional scaling (NMDS) was used to visualize the Bray-Curtis dissimilarity matrices based on the T-RFLP data from soils collected on day 7 of the incubation. Permutational multivariate analysis of variance (PERMANOVA) was performed to examine the significance of Bray-Curtis dissimilarity between treatments, by using the adonis function of the vegan package in $\mathrm{R}$ platform.

\section{Results}

\section{Soil physical and chemical properties}

The physical and chemical properties of the soil samples were highly variable across the nine sampling sites (Table 1). Briefly, soil $\mathrm{pH}$ values varied from 5.44 in V-PB to 7.96 in V-WB, and mineral $\mathrm{N}$ contents shifted between 10.6 and $31.8 \mu \mathrm{g} \mathrm{g}^{-1}$ soil for exchangeable $\mathrm{NH}_{4}{ }^{+}-\mathrm{N}$ and 8.3 and $78.5 \mu \mathrm{g} \mathrm{g}^{-1}$ soil for $\mathrm{NO}_{3}{ }^{-} \mathrm{N}$. Soil organic matter ranged widely from 1.35 to $7.30 \%$, and total $\mathrm{N}$ ranged from 0.05 to $0.49 \%$, with higher values recorded in $\mathrm{P}$ DK and P-FL soils. The wide range of the shift in soil properties 
provided a good opportunity to explore the effect of DMPP across various soil orders and the three land uses.

\section{Dynamics of mineral $\mathrm{N}$ and net nitrification rates}

In the control treatments, the exchangeable $\mathrm{NH}_{4}{ }^{+} \mathrm{N}$ concentrations remained low and almost unchanged around a level of $10 \mu \mathrm{g} \mathrm{g}^{-1}$ soil for all the examined soils (Fig. 1). In the $\mathrm{NH}_{4} \mathrm{NO}_{3}$ treatments, the exchangeable $\mathrm{NH}_{4}{ }^{+}-\mathrm{N}$ concentrations decreased over time, with dramatic declines towards the control levels in P-DK, P-FL, W-FL 1 , W-HS, V-CD, and V-WB soils within 2 weeks, while DMPP amendment significantly slowed down the decline of exchangeable $\mathrm{NH}_{4}{ }^{+} \mathrm{N}$ in these soils $(P<0.05)$. However, regardless of DMPP addition, the exchangeable $\mathrm{NH}_{4}{ }^{+}-\mathrm{N}$ concentrations in P-GN, W-FL2, and VPB soils remained much higher than those in the control treatments until the end of the incubation on day 28.

The $\mathrm{NO}_{3}{ }^{-} \mathrm{N}$ concentrations gradually increased in the control microcosms (Fig. 2), indicative of the oxidation of $\mathrm{NH}_{3}$ derived from the mineralization of native organic $\mathrm{N}$. Addition of $\mathrm{NH}_{4} \mathrm{NO}_{3}$ significantly increased the $\mathrm{NO}_{3}{ }^{-} \mathrm{N}$ concentrations over time $(P<0.05)$, which coincided with the dramatic declines in exchangeable $\mathrm{NH}_{4}{ }^{+} \mathrm{N}$, indicating the occurrence of nitrification. In treatments amended with DMPP, nitrification was evidently reduced by DMPP at certain sampling points. The net nitrification rates for all soils attained the highest values in the $\mathrm{NH}_{4} \mathrm{NO}_{3}$ treatments in the first week of incubation, and DMPP exerted significant inhibition on the net nitrification rates in P-FL, W-FL 1 , W-HS, V-CD, and VWB soils $(P<0.05)$, which varied between 23.4 and $63.6 \%$ (Table 2). The net nitrification rates substantially decreased at the end of incubation, and no significant difference was observed in treatments with or without DMPP.

\section{Changes in the abundance of $\mathrm{AOB}$ and $\mathrm{AOA}$}

The abundance of AOB and AOA in the V-PB soil was below the detection limit of qPCR analysis; therefore, it is not shown in Fig. 3. The abundance of AOB in the control treatment varied greatly from $2.62 \times 10^{4}$ copies $\mathrm{g}^{-1}$ soil in $\mathrm{W}-\mathrm{FL}_{2}$ soil to $8.13 \times 10^{8}$ copies $\mathrm{g}^{-1}$ soil in $\mathrm{V}$-WB soil, and was evidently higher in vegetable soils than in pasture and wheat soils, except for P-FL soil (Fig. 3). Addition of $\mathrm{NH}_{4} \mathrm{NO}_{3}$ significantly increased AOB abundance in W-HS and V-WB soils on day 7 , compared with the control treatments, while DMPP significantly decreased the AOB abundance by 69.1 and $51.4 \%$, respectively. In the $\mathrm{NH}_{4} \mathrm{NO}_{3}$ treatments, the abundance of $\mathrm{AOB}$ was observed to significantly increase in P-GN, P-FL, W-HS, V$\mathrm{CD}$, and V-WB soils on day $28(P<0.05)$. However, significant decreases in the AOB abundance due to DMPP addition were only found in W-HS and V-WB soils on day 28 $(P<0.05)$. The AOA abundance was highest in the vegetable
Table 2 The average net nitrification rates of the three treatments across the three land uses during the first week of incubation and the 28-day incubation

\begin{tabular}{llllll}
\hline Soils & Time intervals & \multicolumn{2}{l}{ Net nitrification rates } & \multirow{2}{*}{$\begin{array}{l}\text { Percent inhibition } \\
\text { by DMPP }\end{array}$} \\
\cline { 3 - 5 } & & Control & $\mathrm{NH}_{4} \mathrm{NO}_{3}$ & $\mathrm{NH}_{4} \mathrm{NO}_{3}+\mathrm{DMPP}$ & \\
\hline P-DK & $d_{0}-d_{7}$ & $3.22 \pm 0.14 \mathrm{a}$ & $11.16 \pm 0.52 \mathrm{~b}$ & $11.61 \pm 0.21 \mathrm{~b}$ & Nil \\
& $d_{0}-d_{28}$ & $3.15 \pm 0.12 \mathrm{a}$ & $5.26 \pm 0.15 \mathrm{~b}$ & $5.10 \pm 0.07 \mathrm{~b}$ & Nil \\
P-GN & $d_{0}-d_{7}$ & $0.78 \pm 0.26 \mathrm{a}$ & $2.58 \pm 0.14 \mathrm{~b}$ & $2.71 \pm 0.35 \mathrm{~b}$ & Nil \\
& $d_{0}-d_{28}$ & $0.87 \pm 0.09 \mathrm{a}$ & $1.63 \pm 0.27 \mathrm{~b}$ & $1.39 \pm 0.02 \mathrm{~b}$ & Nil \\
P-FL & $d_{0}-d_{7}$ & $2.88 \pm 0.14 \mathrm{a}$ & $11.90 \pm 0.15 \mathrm{c}$ & $9.12 \pm 0.34 \mathrm{~b}$ & 23.4 \\
& $d_{0}-d_{28}$ & $2.28 \pm 0.01 \mathrm{a}$ & $4.50 \pm 0.02 \mathrm{~b}$ & $4.18 \pm 0.24 \mathrm{~b}$ & Nil \\
W-FL 1 & $d_{0}-d_{7}$ & $2.37 \pm 0.62 \mathrm{a}$ & $4.37 \pm 0.30 \mathrm{~b}$ & $2.42 \pm 0.99 \mathrm{a}$ & 44.6 \\
& $d_{0}-d_{28}$ & $1.66 \pm 0.32 \mathrm{a}$ & $3.14 \pm 0.14 \mathrm{~b}$ & $2.97 \pm 0.34 \mathrm{~b}$ & Nil \\
W-FL 2 & $d_{0}-d_{7}$ & $1.88 \pm 0.17 \mathrm{a}$ & $3.64 \pm 0.08 \mathrm{~b}$ & $2.88 \pm 0.40 \mathrm{~b}$ & 20.9 \\
& $d_{0}-d_{28}$ & $1.27 \pm 0.05 \mathrm{a}$ & $2.41 \pm 0.05 \mathrm{~b}$ & $2.42 \pm 0.06 \mathrm{~b}$ & Nil \\
W-HS & $d_{0}-d_{7}$ & $1.62 \pm 0.12 \mathrm{a}$ & $9.42 \pm 0.16 \mathrm{~b}$ & $3.43 \pm 0.95 \mathrm{a}$ & 63.6 \\
& $d_{0}-d_{28}$ & $1.62 \pm 0.06 \mathrm{a}$ & $3.56 \pm 0.16 \mathrm{~b}$ & $3.37 \pm 0.25 \mathrm{~b}$ & Nil \\
V-CD & $d_{0}-d_{7}$ & $2.08 \pm 0.22 \mathrm{a}$ & $11.70 \pm 0.26 \mathrm{c}$ & $8.76 \pm 0.67 \mathrm{~b}$ & 25.1 \\
& $d_{0}-d_{28}$ & $2.22 \pm 0.07 \mathrm{a}$ & $4.12 \pm 0.08 \mathrm{~b}$ & $4.00 \pm 0.08 \mathrm{~b}$ & Nil \\
V-WB & $d_{0}-d_{7}$ & $5.11 \pm 0.47 \mathrm{a}$ & $14.06 \pm 0.87 \mathrm{c}$ & $8.31 \pm 0.62 \mathrm{~b}$ & 40.9 \\
& $d_{0}-d_{28}$ & $2.67 \pm 0.15 \mathrm{a}$ & $4.54 \pm 0.21 \mathrm{~b}$ & $4.13 \pm 0.17 \mathrm{~b}$ & Nil \\
V-PB & $d_{0}-d_{7}$ & $0.30 \pm 0.12 \mathrm{a}$ & $0.63 \pm 0.20 \mathrm{a}$ & $0.63 \pm 0.11 \mathrm{a}$ & Nil \\
& $d_{0}-d_{28}$ & $0.42 \pm 0.02 \mathrm{a}$ & $0.56 \pm 0.19 \mathrm{a}$ & $0.57 \pm 0.03 \mathrm{a}$ & Nil \\
\hline
\end{tabular}

The rates were expressed as mean \pm standard errors. The unit is $\mu \mathrm{g} \mathrm{g}^{-1}$ soil day ${ }^{-1}$. Different letters in the same row denote the significant difference at the $P<0.05$ level; nil denotes that no observed inhibition was derived from DMPP addition 


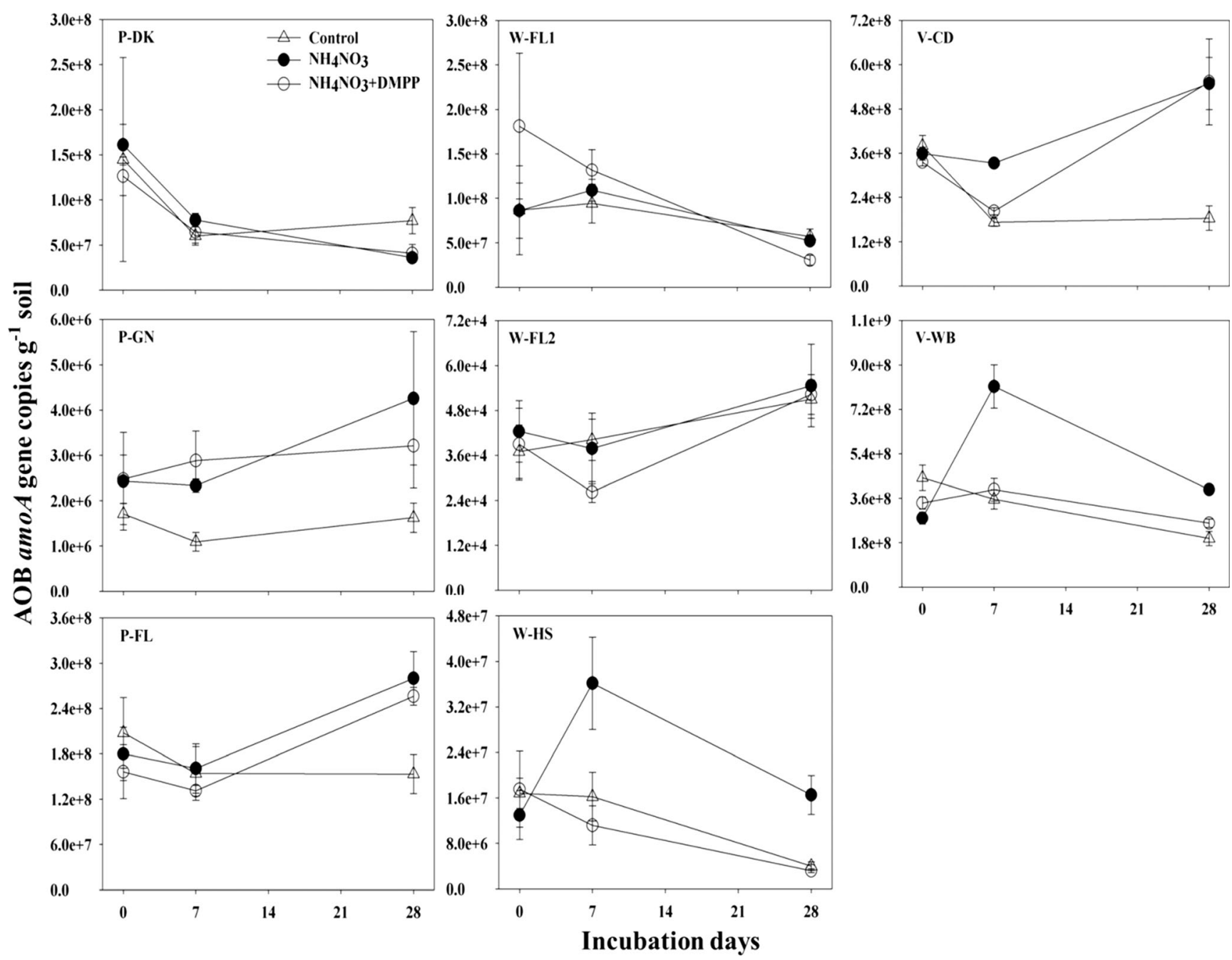

Fig. 3 Changes in the AOB abundance during the 28-day microcosm incubation of soils in the three land uses (pasture, wheat, and vegetable) during the 28-day microcosm incubation. Error bars represent the standard errors of three replicates. Note that $y$ axes scales differ between charts

soils ranging from $1.55 \times 10^{7}$ to $1.35 \times 10^{8}$ copies $\mathrm{g}^{-1}$ soil and much lower in the pasture and wheat soils ranging between $5.73 \times 10^{4}$ and $2.18 \times 10^{6}$ copies $\mathrm{g}^{-1}$ soil (Fig. 4). However, there was no significant difference in the AOA abundance between treatments during the incubation.

Pearson's correlation analysis revealed that the AOB abundance showed significant correlations with $\mathrm{NO}_{3}{ }^{-} \mathrm{N}$ concentrations in pasture soils $\left(R^{2}=0.44, P<0.001\right)$, wheat soils $\left(R^{2}=0.32, P<0.01\right)$, and vegetable soils $\left(R^{2}=0.31, P<0.05\right)$. However, significant correlation between AOA abundance and $\mathrm{NO}_{3}{ }^{-}-\mathrm{N}$ was only observed in pasture soils $\left(R^{2}=0.30, P<0.01\right.$; Fig. 5$)$.

\section{Effects of DMPP on the community composition of AOB and $\mathrm{AOA}$}

The community composition of AOB and AOA in soils collected on days 0 and 7 of the incubation was analyzed using TRFLP. After being digested by the MspI enzyme, the AOB
amoA gene yielded 14 distinct TRFs across land uses. Canonical correspondence analysis (CCA) showed that soil organic matter $(F=2.24, P=0.002)$ and soil $\mathrm{pH}(F=2.02$, $P=0.002)$ were the two most influential soil properties explaining the $\mathrm{AOB}$ community composition, with the first two axes of the CCA accounting for $63.9 \%$ of the total variance. The CCA biplots showed that the AOB community from the same land use formed the same cluster (Fig. 6). NMDS ordinations based on the Bray-Curtis dissimilarity matrices revealed a clear divergence of $\mathrm{AOB}$ assemblages between different soils (Fig. 7), which was further corroborated by the PERMANOVA analysis (pseudo- $F=6.7$, $P<0.001)$.

The AOA amoA gene digested by the RsaI enzyme yielded nine TRFs. Canonical correspondence analysis showed that soil $\mathrm{pH}(F=1.49, P=0.014)$ and indigenous $\mathrm{NO}_{3}{ }^{-} \mathrm{N}(F=1.46, P=0.040)$ were the significant environmental factors explaining the AOA community composition, with the first two axes standing for $52.9 \%$ of the 


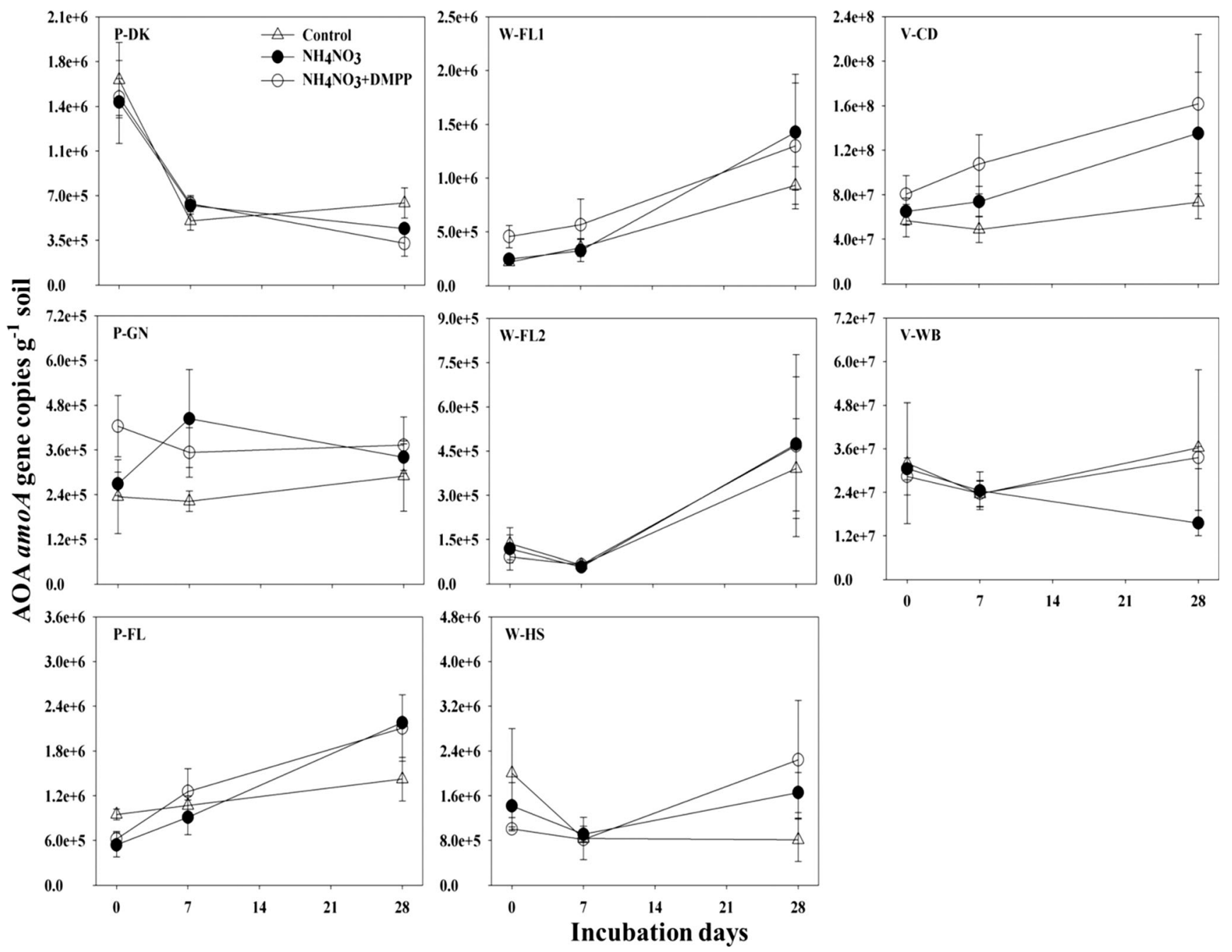

Fig. 4 Changes in the AOA abundance during the 28-day microcosm incubation of soils in the three land uses (pasture, wheat, and vegetable) during the 28-day microcosm incubation. Error bars represent the standard errors of three replicates. Note that $y$ axes scales differ between charts

total AOA variance (Fig. 6). NMDS ordinations showed no clear divergence between treatments (Fig. 7). The PERMANOVA analysis suggested that the land use had a significant impact on the AOA community profiling composition (pseudo- $F=2.4, P<0.001$ ).

\section{Discussion}

\section{DMPP inhibits nitrification through impairing the abundance of $\mathrm{AOB}$}

We found that the DMPP played a significant inhibitory role in the soils with $\mathrm{pH}$ ranging between 6.28 and 7.96 , whereas no DMPP-related inhibition on nitrification was observed in soils with $\mathrm{pH}$ between 5.44 and 5.65 (Tables 1 and 2). Recent studies suggested that soil $\mathrm{pH}$ is a critical factor driving the niche partitioning of AOB and AOA (as detailed reviewed by $\mathrm{Hu}$ et al. 2014). On one hand, neutral and slightly alkaline soils were generally considered as favorable habitats for AOB growth (Shen et al. 2008; Jia and Conrad 2009), and AOB could not be capable of oxidizing $\mathrm{NH}_{3}$ under extremely low soil pH conditions (De Boer and Kowalchuk 2001). The explanation for the inability of $\mathrm{AOB}$ to nitrify $\mathrm{NH}_{3}$ under acid conditions is the exponential ionization of $\mathrm{NH}_{3}$ to $\mathrm{NH}_{4}{ }^{+}$in acid soils (Hu et al. 2014). In this study, the highest AOB abundance was observed in the vegetable soils V-CD $(\mathrm{pH}$ 7.02) and V-WB ( $\mathrm{pH}$ 7.96) soils, whereas the lowest AOB abundance appeared in P-GN (pH 5.55) and W-FL2 (pH 5.49) soils (Fig. 3). On the other hand, numerous studies indicated that AOA plays a more dominant role in mediating nitrification in acid soils, with comprehensive evidence provided by the ${ }^{13} \mathrm{CO}_{2}$-DNA-SIP and 454 bar-coded pyrosequencing techniques (Zhang et al. 2012; Hu et al. 2013). In this study, a higher abundance of AOA than AOB was only found in $\mathrm{W}-\mathrm{FL}_{2}$ soil with the lowest $\mathrm{pH}$ of 5.49 among the investigated soils. Despite that a higher abundance of AOB than AOA was observed in other acid soils including P-DK, P- 
AOB

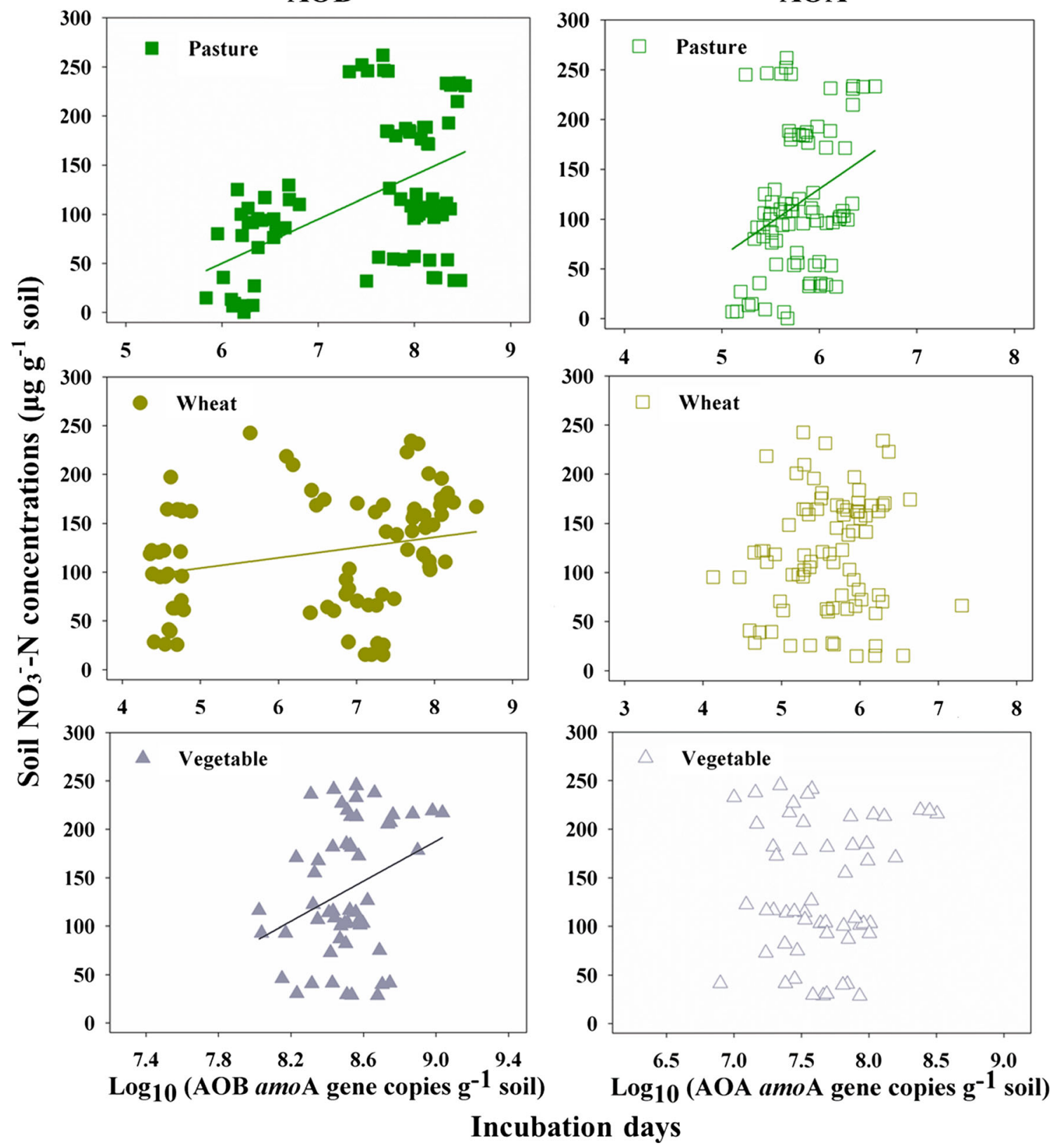

Fig. 5 Relationship between $\mathrm{AOB}$ or $\mathrm{AOA}$ abundance and the $\mathrm{NO}_{3}{ }^{-}-\mathrm{N}$ concentrations during the 28-day microcosm incubation

GN, and V-PB soils, previous research revealed that the numerical advantage at genomic level does not necessarily equal the dominance at functional level (Jia and Conrad 2009). It should be noted that the nitrification rate of P-DK soil was much higher than other acid soils, and could be probably ascribed to the oxidation of $\mathrm{NH}_{3}$ derived from the mineralization of native organic $\mathrm{N}$, as suggested by the rapid increase in nitrate content in the control treatment. This is probably facilitated by the higher organic $\mathrm{N}$ in P-DK soil (Table 2). However, no significantly inhibitory effect of DMPP was observed in these acid soils during the incubation. Taken together, it could be inferred that DMPP has an inhibitory effect on soil nitrification through impairing the $\mathrm{AOB}$ abundance favored by the higher soil $\mathrm{pH}$ conditions, whereas DMPP was not efficient at decreasing nitrification in acid soils.

The different responses of AOB and AOA to DMPP inhibition could be ascribed to not only the $\mathrm{pH}$-associated niche differentiation but also the different enzyme systems for nitrification. Firstly, it is conventionally considered that hydroxylamine $\left(\mathrm{NH}_{2} \mathrm{OH}\right)$ acts as the intermediate of ammonia oxidation $\left(\mathrm{NH}_{3} \rightarrow \mathrm{NH}_{2} \mathrm{OH}\right)$, catalyzed by the AMO enzyme, and DMPP could inhibit nitrification through inactivation of the AMO activity (Benckiser et al. 2013). However, the 


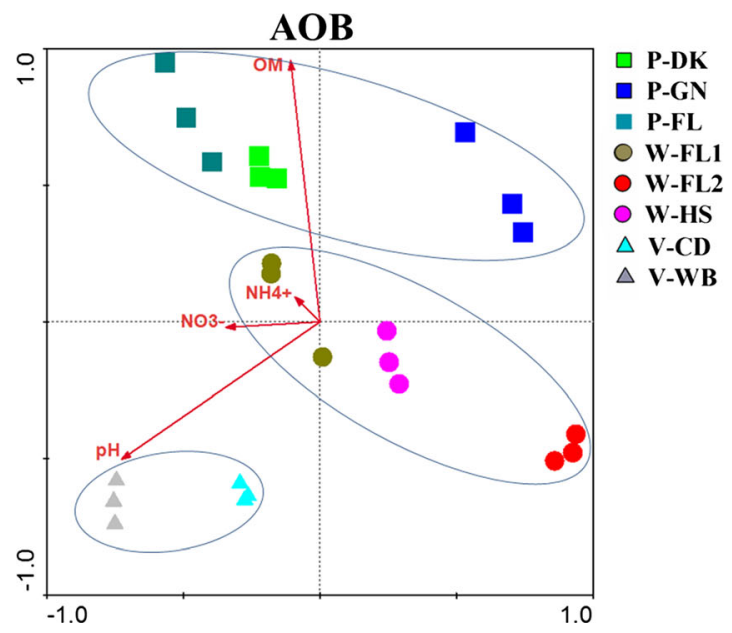

Fig. 6 CCA ordination biplots indicating the relationship between the community composition $\mathrm{AOB}$ or AOA and soil properties in the three land uses (pasture, wheat, and vegetable) before incubation. Arrows

homologous gene encoding the hydroxylamine oxidoreductase ( $\mathrm{HAO}$ ), which is a necessity for the oxidation of $\mathrm{NH}_{2} \mathrm{OH}$, has not been identified in AOA genomes (Tourna et al. 2011). It is speculated that AOA could possess a unique way of nitrification, unlike AOB. One alternative is that AOA could produce nitroxyl hydride (HNO) as an intermediate of ammonia oxidation $\left(\mathrm{NH}_{3} \rightarrow \mathrm{HNO}\right.$ ) (Walker et al. 2010). Secondly, the annotated AOA amo sequences were more similar to the genes encoding bacterial particulate methane monooxygenases (pMMO) rather than $\mathrm{AOB}$ amoA genes, indicative of functional differences in $\mathrm{AMO}$ between $\mathrm{AOA}$ and $\mathrm{AOB}$, which is responsible for the oxidation of $\mathrm{NH}_{3}$ to $\mathrm{NH}_{2} \mathrm{OH}$ (Walker et al. 2010). An early study reported that DMPP reduced AMO activity, while MMO stayed unimpaired in an agricultural crop rotation (Weiske et al. 2001). Therefore, DMPP could not inhibit the AOA-mediated nitrification. Thirdly, the possibility of heterotrophic growth has been suggested for AOA (Tourna et al. 2011), such as group I.1c, well known as a major lineage of AOA (Lehtovirta et al. 2009). The potential of heterotrophic nitrification was further suggested by $\mathrm{Hu}$ et al. (2013), who found that the group I.1c abundance had a significant positive correlation with soil organic C. Therefore, DMPP could inhibit nitrification by inhibiting $\mathrm{AOB}$ growth, and the inefficiency of DMPP on AOA-mediated nitrification could be caused by the different enzyme systems and the mixotrophic growth of AOA.

\section{Environmental and edaphic factors influencing DMPP efficacy}

It has been more than a decade since the earliest report regarding the use of DMPP to regulate $\mathrm{N}$ supply through maintaining $\mathrm{N}$ as $\mathrm{NH}_{4}{ }^{+}$and reducing $\mathrm{NO}_{3}{ }^{-}$leaching, consequently improving NUE (Serna et al. 2000; Zerulla et al. 2001), decreasing greenhouse gas emissions, and increasing crop yields (Pasda et al. 2001; Weiske et al. 2001). Given these benefits

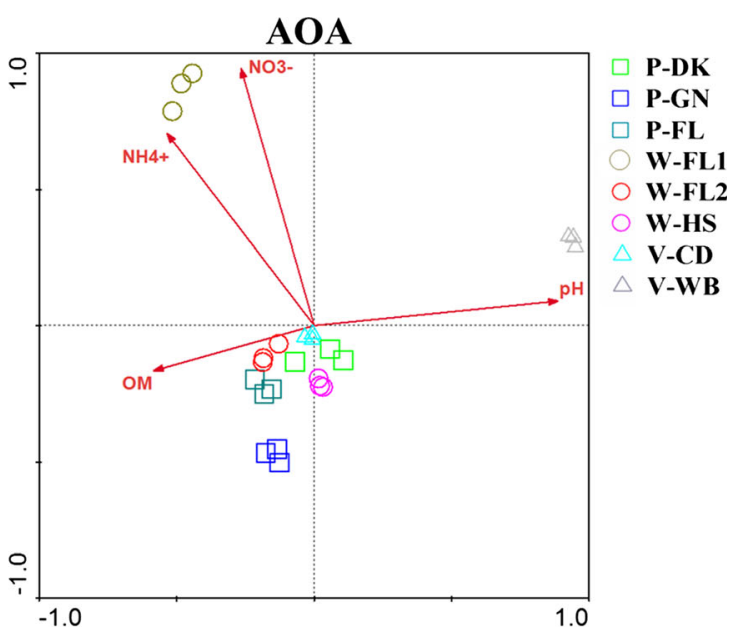

indicate the direction and magnitude of measurable variables associated with the microbial community composition

derived from DMPP application, the factors influencing the efficacy of DMPP have attracted considerable research interest. Soil temperature has been considered as one of the most important factors controlling DMPP efficacy, because temperature has the great potential to impact the mobility of DMPP and the degradation rate of the DMPP in soils (Azam et al. 2001; Irigoyen et al. 2003). In our study, DMPP slowed down the decline of exchangeable $\mathrm{NH}_{4}{ }^{+} \mathrm{N}$ in 1 or 2 weeks; the longest extension was observed in $\mathrm{W}-\mathrm{FL}_{1}$ and $\mathrm{W}-\mathrm{HS}$ soils till the end of incubation at $25{ }^{\circ} \mathrm{C}$ (Figs. 1 and 2), which was comparable with previous studies that showed that DMPP retained exchangeable $\mathrm{NH}_{4}{ }^{+}-\mathrm{N}$ for 8 days at $30^{\circ} \mathrm{C}$ and 40 days at $20^{\circ} \mathrm{C}$ (Irigoyen et al. 2003; Menéndez et al. 2012). However, regardless of DMPP addition, the $\mathrm{NH}_{4}{ }^{+}-\mathrm{N}$ remained at high levels in $\mathrm{P}-\mathrm{GN}, \mathrm{W}-\mathrm{FL}_{2}$, and V-PB soils till day 28. The different changes in exchangeable $\mathrm{NH}_{4}{ }^{+}-\mathrm{N}$ under the same temperature indicate that indigenous nitrification rates in different soils are more critical factor influencing the potential of DMPP to retain $\mathrm{NH}_{4}{ }^{+}-\mathrm{N}$.

The effect of soil properties on DMPP efficacy was first reported by Barth et al. (2001) through a short-term incubation experiment, suggesting that soil textural properties, specifically the proportion of clay, are important factors influencing the binding behavior of positively charged DMPP. In this study, the inhibitory effects of DMPP on net nitrification rates were generally higher in the soils with clay fractions less than $10 \%$ (W-HS, V-CD, and P-FL soils). This is well supported by the previous findings that the inhibitory effects of DMPP were lower in soils with high proportions of clay (Wu et al. 2007; Barth et al. 2008), probably because more DMPP is adsorbed by soil components, resulting in less amount of DMPP to inhibit nitrification (Roco and Blu 2006). However, DMPP inhibited nitrification by $40.9 \%$ in V-WB soil in the first week, even with $36 \%$ clay content in this study (Tables 1 and 2). As suggested by McGeough et al. (2016), clay sorption capacity 
AOB
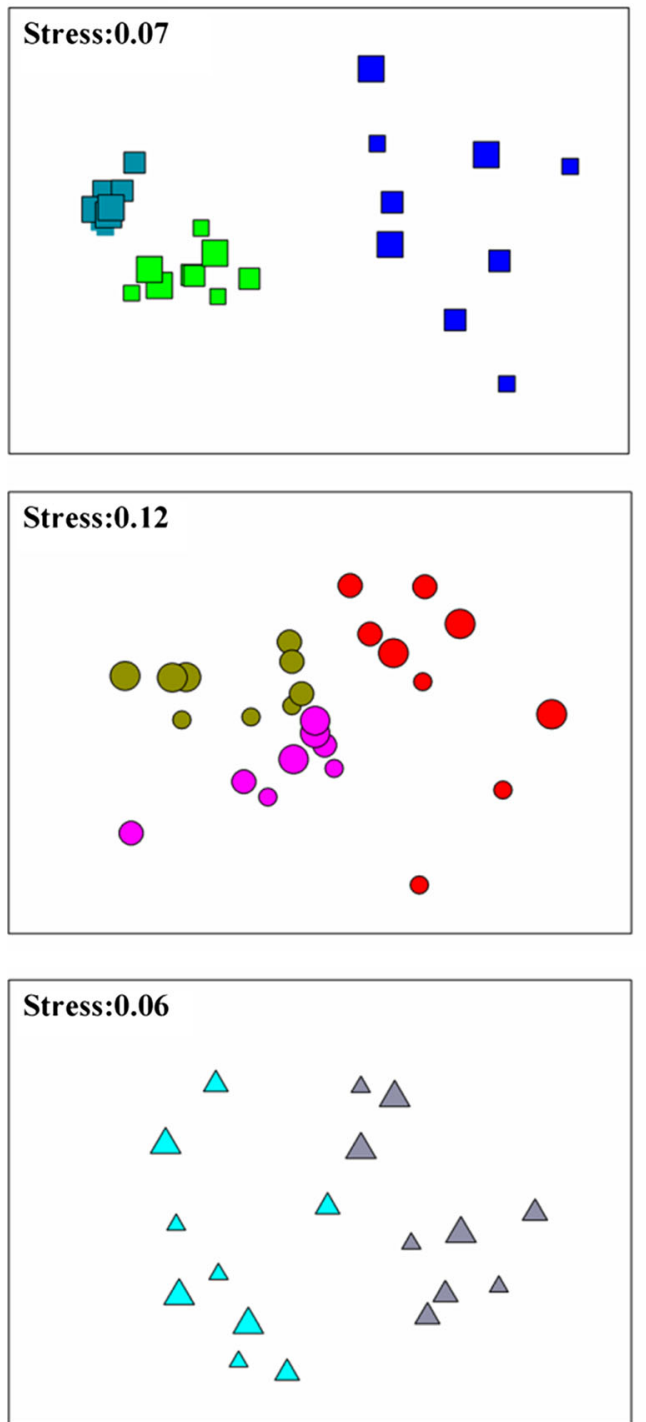

Fig. 7 Non-metric multidimensional scaling ordinations based on the Bray-Curtis dissimilarity matrices of the T-RFLP data of AOB digested using the MspI enzyme and AOA digested using the RsaI enzyme across

was not only dependent on the proportion of clay fraction but also on the type of clay minerals. Therefore, the proportion and type of clay in soils should be determined to better understand their effects on DMPP efficacy in future studies. Apart from clay fractions, soil organic matter is suggested as another important soil component involved in the sorption of organic compounds (Kelliher et al. 2008; McGeough et al. 2016). In this study, the soil organic matter content is generally higher in the pasture soils than in the wheat and vegetable soils (Table 1); consequently, the higher inhibitory effect of DMPP on net nitrification found in the latter two soils could be due to the lower organic matter (Table 2). Recently, Marsden et al. (2016) reported that the sorption of DMPP was higher in the soil with higher amount of organic matter with the ${ }^{14} \mathrm{C}$-labeled DMPP applied in three distinct soils. The sorption phenomenon by
AOA

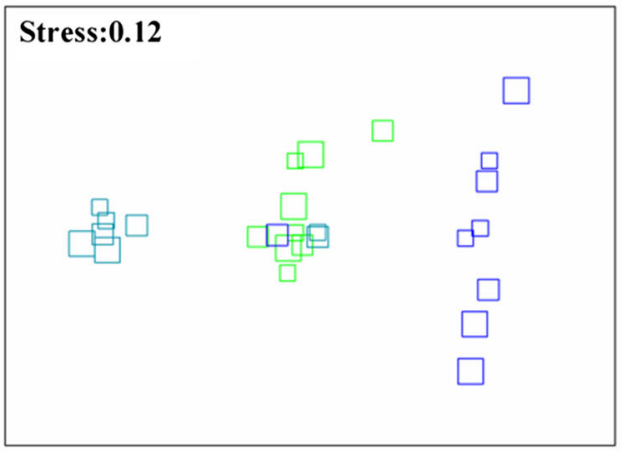

P-DK-C

P-DK-F

P-DK-FD

P-GN-C

P-GN-F

P-GN-FD

P-FL-C

P-FL-F

P-FL-FD

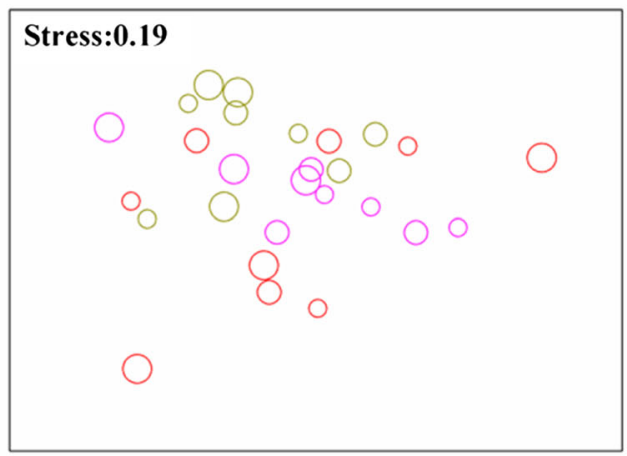

W-FL1-C

W-FL1-F

W-FL1-FD

W-FL2-C

W-FL2-F

W-FL2-FD

W-HS-C

W-HS-F

W-HS-FD

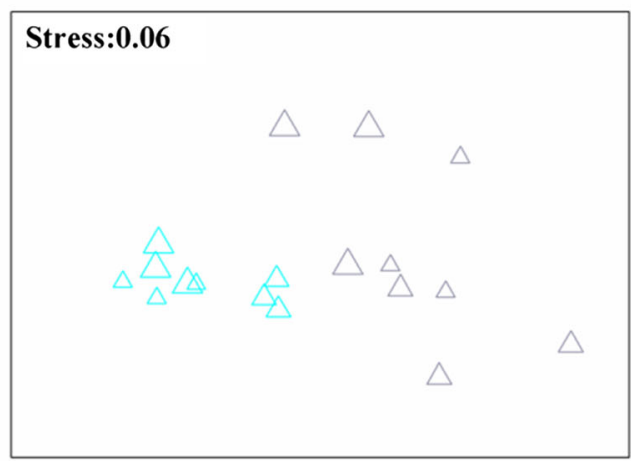

V-CD-C

$\mathrm{V}-\mathrm{CD}-\mathrm{F}$

V-CD-FD

V-WB-C

V-WB-F

V-WB-FD

different treatments ( $C$ control, $\left.F \mathrm{NH}_{4} \mathrm{NO}_{3}, F D \mathrm{NH}_{4} \mathrm{NO}_{3}+\mathrm{DMPP}\right)$ and land uses ( $P$ pasture, $W$ wheat, $V$ vegetable) on day 7 of the incubation

soil organic matter also applies to other NIs, as a metaanalysis conducted by Kelliher et al. (2008) showed that the amount of DCD sorption onto soil organic matter soils is a critical factor determining DCD efficacy. A recent study showed that the efficiency of nitrapyrin diminished over the long-term addition of soil organic matter (Fisk et al. 2015).

\section{Conclusions}

In conclusion, through analysis of functional gene abundance and community composition in microcosm incubation of nine soils across three land uses, we found that only $\mathrm{AOB}$ was significantly decreased by DMPP addition, accompanied by the decreased net nitrification rates. The effectiveness of 
DMPP at reducing nitrification was higher in neutral and alkaline soils, wheat and vegetable soils than in pasture soils, indicating that DMPP could play an inhibitory role in nitrification through impairing AOB growth. We provided evidence that the community composition of ammonia oxidizers were more resilient than gene abundance in response to DMPP addition. Our results indicated that soil clay fractions and organic matter content could be critical factors influencing DMPP efficacy. Further studies involving more soil types under field conditions should be incorporated into future research on the efficacy of DMPP at inhibiting nitrification and nitrifier activity.

Acknowledgments This work was financially supported by Australian Research Council (DE150100870, DP160101028). The authors thank Julian Hill, Harry Velisha, and John Lcay for the soil collections and also Dr. Junjian Li for the assistance with data analysis.

\section{References}

Akiyama H, Yan X, Yagi K (2009) Evaluation of effectiveness of enhanced-efficiency fertilizers as mitigation options for $\mathrm{N}_{2} \mathrm{O}$ and $\mathrm{NO}$ emissions from agricultural soils: meta-analysis. Glob Chang Biol 16:1837-1846

Azam F, Benckiser G, Müller C, Ottow JCG (2001) Release, movement and recovery of 3,4-dimethylpyrazole phosphate (DMPP), ammonium, and nitrate from stabilized nitrogen fertilizer granules in a silty clay soil under laboratory conditions. Biol Fertil Soils 34:118-125

Barth G, Tucher SV, Schmidhalter U (2001) Influence of soil parameters on the effect of 3,4-dimethylpyrazole-phosphate as a nitrification inhibitor. Biol Fertil Soils 34:98-102

Barth G, Von Tucher S, Schmidhalter U (2008) Effectiveness of 3,4dimethylpyrazole phosphate as nitrification inhibitor in soil as influenced by inhibitor concentration, application form, and soil matrix potential. Pedosphere 18:378-385

Benckiser G, Christ E, Herbert T, Weiske A, Blome J, Hardt M (2013) The nitrification inhibitor 3,4-dimethylpyrazole-phosphat (DMPP) - quantification and effects on soil metabolism. Plant Soil 371:257-266

Brochier-Armanet C, Boussau B, Gribaldo S, Forterre P (2008) Mesophilic Crenarchaeota: proposal for a third archaeal phylum, the Thaumarchaeota. Nat Rev Microbiol 6:245-252

Chaves B, Opoku A, De Neve S, Boeckx P, Van Cleemput O, Hofman G (2005) Influence of DCD and DMPP on soil N dynamics after incorporation of vegetable crop residues. Biol Fertil Soils 43:62-68

Chen DL, Suter H, Islam A, EdisA R, Freney JR, Walker CN (2008) Prospects of improving efficiency of fertiliser nitrogen in Australian agriculture a review of enhanced efficiency fertilisers. Aust J Soil Res 46:289-301

Chen Q, Qi L, Bi Q, Dai P, Sun D, Sun C, Liu W, Lu L, Ni W, Lin X (2015) Comparative effects of 3,4-dimethylpyrazole phosphate (DMPP) and dicyandiamide (DCD) on ammonia-oxidizing bacteria and archaea in a vegetable soil. Appl Microbiol Biotechnol 99:477-487

De Boer W, Kowalchuk GA (2001) Nitrification in acid soils: microorganisms and mechanisms. Soil Biol Biochem 33:853-866

Di HJ, Cameron KC (2011) Inhibition of ammonium oxidation by a liquid formulation of 3,4-dimethylpyrazole phosphate (DMPP) compared with a dicyandiamide (DCD) solution in six new Zealand grazed grassland soils. J Soils Sediments 11:1032-1039
Di HJ, Cameron KC (2012) How does the application of different nitrification inhibitors affect nitrous oxide emissions and nitrate leaching from cow urine in grazed pastures? Soil Use Manage 28:54-61

Dong XX, Zhang LL, Wu ZJ, Li DP, Shang ZC, Gong P (2013) Effects of the nitrification inhibitor DMPP on soil bacterial community in a Cambisol in northeast China. J Soil Sci Plant Nutr 13:580-591

Ernfors M, Brennan FP, Richards KG, McGeough KL, Griffiths BS, Laughlin RJ, Watson CJ, Philippot L, Grant J, Minet EP, Moynihan E, Müller C (2014) The nitrification inhibitor dicyandiamide increases mineralization-immobilization turnover in slurry-amended grassland soil. J Agric Sci 152:137-149

Fangueiro D, Fernandes A, Coutinho J, Moreira N, Trindade H (2009) Influence of two nitrification inhibitors (DCD and DMPP) on annual ryegrass yield and soil mineral $\mathrm{N}$ dynamics after incorporation with cattle slurry. Commun Soil Sci Plan 40:3387-3398

Fisk LM, Maccarone LD, Barton L, Murphy DV (2015) Nitrapyrin decreased nitrification of nitrogen released from soil organic matter but not $a m o A$ gene abundance at high soil temperature. Soil Biol Biochem 88:214-223

Florio A, Clark IM, Hirsch PR, Jhurreea D, Benedetti A (2014) Effects of the nitrification inhibitor 3,4-dimethylpyrazole phosphate (DMPP) on abundance and activity of ammonia oxidizers in soil. Biol Fertil Soils 50:795-807

Gilsanz C, Báez D, Misselbrook TH, Dhanoa MS, Cárdenas LM (2016) Development of emission factors and efficiency of two nitrification inhibitors, DCD and DMPP. Agric Ecosyst Environ 216:1-8

Hatch D, Trindade H, Cardenas L, Carneiro J, Hawkins J, Scholefield D, Chadwick D (2005) Laboratory study of the effects of two nitrification inhibitors on greenhouse gas emissions from a slurry-treated arable soil: impact of diurnal temperature cycle. Biol Fertil Soils 41:225-232

Hu HW, Zhang LM, Dai Y, Di HJ, He JZ (2013) pH-dependent distribution of soil ammonia oxidizers across a large geographical scale as revealed by high-throughput pyrosequencing. J Soils Sediments 13: 1439-1449

Hu HW, Xu ZH, He JZ (2014) Ammonia-oxidizing archaea play a predominant role in acid soil nitrification. Adv Agron 125:261-294

Hu HW, Chen D, He JZ (2015a) Microbial regulation of terrestrial nitrous oxide formation: understanding the biological pathways for prediction of emission rates. FEMS Microbiol Rev 39:729-749

Hu HW, Macdonald CA, Trivedi P, Holmes B, Bodrossy L, He JZ, Singh BK (2015b) Water addition regulates the metabolic activity of ammonia oxidizers responding to environmental perturbations in dry subhumid ecosystems. Environ Microbiol 17:444-461

International Fertilizer Industry Association annual report (2014) http://www.fertilizer.org/. Accessed June 2014

Irigoyen I, Muro JM, Azpilikueta Aparicio-Tejo, Lamfus C (2003) Ammonium oxidation kinetics in the presence of nitrification inhibitors DCD and DMPP at various temperatures Aust J Soil Res pp. $1177-1183$.

Isbell RF (2002) The Australian Soil Classification. CSIRO Publishing, Melbourne

Jia Z, Conrad R (2009) Bacteria rather than archaea dominate microbial ammonia oxidation in an agricultural soil. Environ Microbiol 11: $1658-1671$

Kelliher FM, Clough TJ, Clark H, Rys G, Sedcole JR (2008) The temperature dependence of dicyandiamide (DCD) degradation in soils: a data synthesis. Soil Biol Biochem 40:1878-1882

Kleineidam K, Kosmrlj K, Kublik S, Palmer I, Pfab H, Ruser R, Fiedler S, Schloter M (2011) Influence of the nitrification inhibitor 3,4dimethylpyrazole phosphate (DMPP) on ammonia-oxidizing bacteria and archaea in rhizosphere and bulk soil. Chemosphere 84:182-186

Kong X, Duan Y, Schramm A, Eriksen J, Petersen SO (2016) 3,4Dimethylpyrazole phosphate (DMPP) reduces activity of ammonia oxidizers without adverse effects on non-target soil microorganisms and functions. Appl Soil Ecol 105:67-75 
Lehtovirta LE, Prosser JI, Nicol GW (2009) Soil pH regulates the abundance and diversity of group 1.1c Crenarchaeota. FEMS Microbiol Ecol 70:367-376

Liu C, Wang K, Zheng X (2013) Effects of nitrification inhibitors (DCD and DMPP) on nitrous oxide emission, crop yield and nitrogen uptake in a wheat-maize cropping system. Biogeosci Discuss 10: 711-737

Liu R, Suter H, Hayden H, He J, Chen D (2015) Nitrate production is mainly heterotrophic in an acid dairy soil with high organic content in Australia. Biol Fertil Soils 51:891-896

Maienza A, Bååth E, Stazi SR, Benedetti A, Grego S, Dell'Abate MT (2014) Microbial dynamics after adding bovine manure effluent together with a nitrification inhibitor (3,4 DMPP) in a microcosm experiment. Biol Fertil Soils 50:869-877

Marsden KA, Marín-Martínez AJ, Vallejo A, Hill PW, Jones DL, Chadwick DR (2016) The mobility of nitrification inhibitors under simulated ruminant urine deposition and rainfall: a comparison between DCD and DMPP. Biol Fertil Soils 52:491-503

McCarty GW, Bremner JM (1989) Inhibition of nitrification in soil by heterocyclic nitrogen compounds. Biol Fertil Soils 8:204-211

McGeough KL, Watson CJ, Müller C, Laughlin RJ, Chadwick DR (2016) Evidence that the efficacy of the nitrification inhibitor dicyandiamide (DCD) is affected by soil properties in UK soils. Soil Biol Biochem 94:222-232

Menéndez S, Merino P, Pinto M, Gonzalez-Murua C, Estavillo JM (2009) Effect of $\mathrm{N}$-(n-butyl) thiophosphoric triamide and 3,4dimethylpyrazole phosphate on gaseous emissions from grasslands under different soil water contents. J Environ Qual 38:27-35

Menéndez S, Barrena I, Setien I, González-Murua C, Estavillo JM (2012) Efficiency of nitrification inhibitor DMPP to reduce nitrous oxide emissions under different temperature and moisture conditions. Soil Biol Biochem 53:82-89

Migliorati MDA, Scheer C, Grace PR, Rowlings DW, Bell M, McGree J (2014) Influence of different nitrogen rates and DMPP nitrification inhibitor on annual $\mathrm{N}_{2} \mathrm{O}$ emissions from a subtropical wheat-maize cropping system. Agric Ecosyst Environ 186:33-43

Pasda G, Hähndel R, Zerulla W (2001) Effect of fertilizers with the new nitrification inhibitor DMPP (3,4-dimethylpyrazole phosphate) on yield and quality of agricultural and horticultural crops. Biol Fertil Soils 34:85-97

Persson T, Wirén A (1995) Nitrogen mineralization and potential nitrification at different depths in acid forest soils. Plant Soil 168:55-65

Philippot L, Hallin S, Schloter M (2007) Ecology of denitrifying prokaryotes in agricultural soil. Adv Agron 96:249-305

Purkhold U, Pommerening-Roser A, Juretschko S, Schmid MC, Koops HP, Wagner M (2000) Phylogeny of all recognized species of ammonia oxidizers based on comparative $16 \mathrm{~S}$ rRNA and amoA sequence analysis implications for molecular diversity surveys. Appl Environ Microbiol 66:5368-5382

Roco MM, Blu RO (2006) Evaluation of the nitrification inhibitor 3, 4-dimethylpyrazole phosphate in two Chilean soils. J Plant Nutr 29:521-534

Rotthauwe JH, Witzel KP, Liesack W (1997) The ammonia monooxygenase structural gene amoA as a functional marker: molecular fine-scale analysis of natural ammonia-oxidizing populations. Appl Environ Microbiol 63:4704-4712
Serna MD, Baňuls J, Quiňones A, Primo-Millo E, Legaz F (2000) Evaluation of 3,4-dimethylpyrazole phosphate as a nitrification inhibitor in a citrus-cultivated soil. Biol Fertil Soils 32:41-46

Shen JP, Zhang LM, Zhu YG, Zhang JB, He JZ (2008) Abundance and composition of ammonia-oxidizing bacteria and ammonia-oxidizing archaea communities of an alkaline sandy loam. Environ Microbiol 10:1601-1611

Shi XZ, Hu HW, He JZ, Chen DL, Suter H (2016) Effects of the nitrification inhibitor 3,4-dimethylpyrazole phosphate (DMPP) on nitrification and nitrifiers in two contrasting agricultural soils. Appl Environ Microbiol. doi:10.1128/AEM.01031-16

Singh BK, Thomas N (2006) Multiplex-terminal restriction fragment length polymorphism. Nat Protoc 1:2428-2433

Tindaon F, Benckiser G, Ottow JCG (2012) Evaluation of ecological doses of the nitrification inhibitors 3,4-dimethylpyrazole phosphate (DMPP) and 4-chloromethylpyrazole (ClMP) in comparison to dicyandiamide (DCD) in their effects on dehydrogenase and dimethyl sulfoxide reductase activity in soils. Biol Fertil Soils 48:643-650

Tourna M, Freitag TE, Nicol GW, Prosser JI (2008) Growth, activity and temperature responses of ammonia-oxidizing archaea and bacteria in soil microcosms. Environ Microbiol 10:1357-1364

Tourna M, Stieglmeier M, Spang A, Könneke M, Schintlmeister A, Urich T, Engel M, Schloter M, Wagner M, Richter A, Schleper C (2011) Nitrososphaera viennensis, an ammonia oxidizing archaeon from soil. Proc Natl Acad Sci U S A 108:8420-8425

Wakelin S, Williams E, O'Sullivan CA, Cameron KC, Di HJ, Cave V, O'Callaghan M (2014) Predicting the efficacy of the nitrification inhibitor dicyandiamide in pastoral soils. Plant Soil 381:35-43

Walker CB, Torre JR, Klotz MG, Urakawa H, Pinel N, Arp DJ, BrochierArmanet C, Chain PSG (2010) Nitrosopumilus maritimus genome reveals unique mechanisms for nitrification and autotrophy in globally distributed marine Crenarchaea. Proc Natl Acad Sci U S A 107: 8818-8823

Walkley A, Black IA (1934) An examination of the Degtjareff method for determining soil organic matter, and a proposed modification of the chromic acid titration method. Soil Sci 37:29-38

Weiske A, Bnckiser G, Herbert T, Ottow J (2001) Influence of the nitrification inhibitor 3,4-dimethylpyrazole phosphate (DMPP) in comparison to dicyandiamide (DCD) on nitrous oxide emissions, carbon dioxide fluxes and methane oxidation during 3 years of repeated application in field experiments. Biol Fertil Soils 34:109-117

Wu SF, Wu LH, Shi QW, Wang ZQ, Chen XY, Li YH (2007) Effects of a new nitrification inhibitor 3,4-dimethylpyrazole phosphate (DMPP) on nitrate and potassium leaching in two soils. J Environ Sci (China 19:841-847

$\mathrm{Xu} \mathrm{C}, \mathrm{Wu} \mathrm{LH}, \mathrm{Ju}$ XT, Zhang FS (2005) Role of nitrification inhibitor DMPP (3,4-dimethylpyrazole phosphate) in $\mathrm{NO}_{3}^{-}-\mathrm{N}$ accumulation in greengrocery (Brassica campestris L. spp. chinensis) and vegetable soil. J Environ Sci (China 17:81-83

Zerulla W, Barth T, Dressel J, Erhardt K, Horchler von Locquenghien K, Pasda Rädle M, Wissemeier AH (2001) 3,4-Dimethylpyrazole phosphate (DMPP) - a new nitrification inhibitor for agriculture and horticulture. Biol Fertil Soils 34:79-84

Zhang LM, Hu HW, Shen JP, He JZ (2012) Ammonia-oxidizing archaea have more important role than ammonia-oxidizing bacteria in ammonia oxidation of strongly acidic soils. ISME J 6:1032-1045 